\title{
EFFECTS OF CAFFEINE ON VISUAL EVOKED POTENTIAL (P300) AND NEUROMOTOR PERFORMANCE
}

\author{
Andréa Camaz Deslandes ${ }^{1}$, Heloisa Veiga ${ }^{1}$, Maurício Cagy², Roberto Piedade ${ }^{3}$, Fernando Pompeu ${ }^{4}$, Pedro \\ Ribeiro ${ }^{5}$
}

ABSTRACT - The stimulant effects of caffeine on cognitive performance have been widely investigated. The visual evoked potential, specially the P300 component, has been used in studies that explain the stimulant mechanisms of caffeine through neurophysiological methods. In this context, the present study aimed to investigate electrophysiological changes (P300 latency) and modification of cognitive and motor performance produced by caffeine. Fifteen healthy volunteers, 9 women and 6 men ( $26 \pm 5$ years, 67 $\pm 12.5 \mathrm{~kg}$ ) were submitted three times to the following procedure: electroencefalographic recording, Word Color Stroop Test, and visual discrimination task. Subjects took a gelatin caffeine capsule (400 mg) or a placebo (P1 and P2), in a randomized, crossover, double-blind design. A one-factor ANOVA and Tukey' post hoc test were used to compare dependent variables on the C, P1 and P2 moments. The statistical analyses indicated a non-significant decrease in reaction time, Stroop execution time and latency at $\mathrm{Cz}$ on the caffeine moment when compared to the others. Moreover, a non-significant increase in Stroop raw score and latency at Pz could be observed. The only significant result was found at $F$. These findings suggest that the positive tendency of caffeine to improve cognitive performance is probably associated with changes in the frontal cortex, a widely recognized attention area.

KEY WORDS: P300, caffeine, neuromotor performance.

\begin{abstract}
Efeitos da ingestão de cafeína no potencial evocado visual (p300) e no desempenho neuromotor
RESUMO - Os efeitos estimulantes da cafeína no desempenho cognitivo vêm sendo amplamente investigados. 0 potencial evocado visual (P300) tem sido empregado em estudos recentes que buscam elucidar os mecanismos excitatórios da cafeína através de métodos neurofisiológicos. Neste contexto, o presente estudo objetivou examinar as variações geradas pela cafeína em respostas eletrofisiológicas (latência do P300) e determinar modificações no desempenho cognitivo e motor. Para tanto, 15 indivíduos hígidos, sendo 9 mulheres e 6 homens ( $26 \pm 5$ anos, $67 \pm 12,5 \mathrm{~kg}$ ) foram submetidos por três vezes à seguinte rotina: aquisição de sinais eletroencefalográficos, Word Color Stroop Test e tarefa de discriminação visual. Foi administrada uma cápsula gelatinosa de $400 \mathrm{mg}$ de cafeína ou de placebo (P1 e P2) em um desenho randomizado duplo-cego cruzado. Foi empregada a ANOVA com um fator e post hoc de Tukey - HSD para a comparação das variáveis nos momentos C, P1 e P2. 0 momento cafeína apresentou redução não significativa no tempo de reação, no tempo de execução do Stroop e na latência em Cz. Observou-se também aumento não significativo no escore bruto do Stroop e na latência em Pz. 0 único resultado significativo encontrado foi na latência em Fz. Assim, pode-se concluir que a tendência favorável à ingestão de cafeína na melhora das respostas cognitivas pode estar relacionada a mudanças em regiões específicas do cérebro, como o córtex frontal, área amplamente relacionada com os processos de atenção.
\end{abstract}

PALAVRAS-CHAVE: P300, cafeína, desempenho neuromotor.

Caffeine, a 1,3,7-trimethylxanthine, is an acknowledged central nervous system (CNS) stimulant. It is a widely used psychoactive substance, and part of many soft drinks. Although the effects of caffeine on cognitive performance have been subject of numerous experiments, the findings are still not conclu- sive ${ }^{1-4}$. In this sense, the mechanisms of caffeine's ergogenic effects are not well understood. Partial results suggest that caffeine produces an initial enhancement of fat utilization. Moreover, low doses of caffeine $(60 \mathrm{mg})$ affect key aspects of cognitive function related to alertness, vigor, mood, efficien-

${ }^{1}$ M estranda, Setor de Mapeamento Cerebral e Integração Sensório-M otora, Instituto de Psiquiatria (IPUB), Universidade Federal do Rio de Janeiro Rio de Janeiro RJ, Brazil UFRJ; ${ }^{2}$ D.SC. em Engenharia Biomédica, COPPE, UFRJ; ${ }^{3 P r o f e s s o r}$ Adjunto III Doutor, Coordenador do Setor de Mapeamento Cerebral e Integração SensórioMotora, IPUB, UFRJ; ‘ Professor Doutor, Escola de Educação Física e Desportos (EEFD), UFR); ${ }^{5}$ Professor Adjunto II PhD, Escola de Educação Física e Desportos (EEFD), Setor de Mapeamento Cerebral e Integração Sensório-M otora, IPUB, UFRJ; Professor Pesquisador, Universidade Castelo Branco (PROCIMH-UCB).

Received 3 September 2003, received in final form 15 December 2003. Accepted 13 January 2004.

Dra. Andréa Camaz Deslandes - Instituto de Psiquiatria (IPUB), Setor de Neuroimagem Funcional, UFRJ - Avenida Venceslau Brás 71 Fundos - 22290-140 Rio de Janeiro RJ - Brasil. E-mail: andreadeslandes@olimpo.com.br 
$c y$, and perception of energy 5 . Caffeine has also been associated with improvement in motor performance ${ }^{4,6,7}$. Although the greater implications of these effects are unclear, psychomotor improvement was observed in reaction time, hand steadiness, tapping rate and locomotor activity. Moreover, an increase in motor activity and tapping rate, and shorter simple and choice reaction times were observed with low doses of caffeine. In this context, caffeine can be regarded as a neuromotor modulator.

Changes in brain states brought about by caffeine are manifested in the spontaneous background electroencephalogram (EEG). Topographical quantitative EEG (qEEG) measures provide a neurophysiological assessment of brain activity correlated with behavior. Through a detailed examination of the EEG, it was possible to note that the presentation of a stimulus causes alterations in cerebral activity. Such alterations are named evoked potentials (EP) ${ }^{8}$. EEG and EP measures have been used clinically for many years. Specifically, the event-related potentials (ERP) have been used as biological markers in experiments that try to assess brain information processing. The P300 is the most frequently analyzed ERP component and is considered a cognitive component associated to decision-making processes. It reflects neuroelectric activity related to cognitive processes such as attention allocation and activation of immediate memory. P300 is measured by the quantification of its amplitude $(\mu \mathrm{V})$ and latency $(\mathrm{ms})^{8,9}$. It has been suggested that P300 latency is negatively correlated with mental function in normal subjects, i.e., shorter latencies indicate a superior cognitive performance. In this context, this evoked potential component reflects $\mathrm{CNS}$ activity related to cognitive operations and helps to discriminate the effects of stimulant drugs on brain activity. Recent studies also investigated cognitive function and motor control through changes in P300 latency and amplitude $\mathrm{e}^{10-16}$.

Several investigations have examined the effects of caffeine on cognitive and motor function, in an attempt to elucidate possible mechanisms involved. Recent experiments showed a significant increase on psychomotor performance in subjects who ingested caffeine when compared to placebo ${ }^{15,17,18}$. Caffeine's behavioral effects have been documented in a number of laboratories, as well as improvements on attention, mood and vigor tasks. Moreover, a decrease on reaction time and changes on P300 latency ${ }^{15,19}$ and amplitude ${ }^{18}$ have been associated with the modulator effects of caffeine. Nevertheless, worldwide labs have presented contradictory results and different experimental procedures. The most proeminent results were found on specific conditions, such as fatigue, sleep deprivation, withdrawal and hypoglycemia. Polich and $\mathrm{Kok}^{8}$ also suggest that P300/caffeine effects are influenced by the individual's arousal level. Given these inconsistencies, the mechanisms involved in the effects of caffeine on event-related potentials have not been clarified. In this context, the aim of this study was to determine the CNS profile of caffeine intake on the EEG (P300 latency) and neuromotor functions (reaction time and attention demands) in normal subjects with control experimental procedures.

\section{METHOD}

Subjects - The sample consisted of 15 individuals, 6 male and 9 female, with ages varying between 21 and 38 years ( $26 \pm 5$ years), weighing between 51 and $88 \mathrm{~kg}(67 \pm 12.5 \mathrm{~kg})$, and having a caffeine or caffeine-containing beverage consumption of less than four cups per day. All subjects were healthy, free of cognitive deficits and were not making use of any psychoactive or psychotropic substance at the time of the test. To assure that subjects did not present any impairment of their physical and mental health, and to identify and exclude from the experiment any subjects who could contaminate future results, a questionnaire was applied. The questionnaire also aimed to identify possible P300 biological determinants, such as food intake, body temperature, fatigue, drugs, among others. The subjects were not allowed to smoke or to consume alcohololic or caffeine-containing beverages 10 hours prior to and during the test. Subjects signed a consent form, where the experimental condition was thoroughly described. The experiment was submitted to the Psychiatric Institute's ethics committee for approval.

Study design and procedures - The subjects received $400 \mathrm{mg}$ gelatin capsules (caffeine or glucose) on three different occasions under a randomized, double-blind, crossover study. The procedures consisted of a three-day treatment: tw o placebos and one caffeine. All subjects were familiarized with the experimental tasks. The procedures were standardized in the following routine: electroencephalographic recording, administration of the Word Color Stroop Test and visual evoked potential. EEG was recorded 30 min after ingestion of caffeine and placebo.

Eletroencephalogram recording - Subjects were seated comfortably in a sound and light-attenuated room, while 5 minutes of eyesclosed alert/resting and 5 minutes of eyes-open EEG data were collected from the 19 monopolar electrodes sites. International 10 / 20 System (referred to linked earlobes) for electrode placement was used with a Braintech-3000 (EM SA-M edical Instruments, Brazil). All electrode impedances were kept below $5 \mathrm{k} \Omega$. The signal was amplified with a gain of circa 22,000. The EEG signals were acquired between 0.01 and $50 \mathrm{~Hz}$. Eye-movement (EOG) artifact was monitored with a bipolar electrode montage using two 9-mm diameter electrodes attached superior to and on the external canthus of the right eye. The EEG signal was analogically filtered between $0.1 \mathrm{~Hz}$ (high-pass) and $32 \mathrm{~Hz}$ (low-pass), and sampled at $240 \mathrm{~Hz}$. The software ERP Acquisition, developed at the Brain Mapping and Sensorimotor Integration Lab, was employed with the following digital filters: Notch $(60 \mathrm{~Hz})$, high-pass of $0.3 \mathrm{~Hz}$ and low-pass of 25 $\mathrm{Hz}$. Visual inspection was employed for detection and elimination of artifacts.

Stroop test - The Stroop test evaluates focused attention and assesses the integrative power of cognitive mechanisms in reaching decisions based upon information from two different modalities (lexical and perceptual $)^{17}$. First, the subjects were asked to read the 
name of a color and second, to name the printed color of a world denoting a different color (color-word interference). Subjects were asked to perform the task as quickly and as accurately as possible. The Stroop color-naming task is a classic paradigm that elegantly illustrates important concepts such as automaticity and interference ${ }^{20}$.The criteria analyzed were execution time and raw score (number of correct answers).

Event-related potential recordings - During the visual task, lights were turned off for subjects to concentrate exclusively on the monitor screen. A 15" monitor was placed in front of the volunteer. The visual stimulus was presented on the monitor by the ERP acquisition software, developed in Delphi 5.0 (Inprise Co.). Event-related potentials were recorded from the $\mathrm{Fz}, \mathrm{Cz}$ and $\mathrm{Pz}$ electrode sites. The task employed the oddball paradigm. In this paradigm, two stimuli are presented randomly, with one occurring relatively infrequently. Subjects w ere asked to discriminate target (infrequent) from non-target or standard stimuli (frequent). In the present experiment, target stimuli were represented by a square and non-target stimuli by a circle. Subjects were instructed to respond as quickly as possible to the target stimulus by pressing a button in a joystick (M odel Quick ShotCrystal CS4281). The P300 was identified as the largest positive-going peak amplitude of the waveform within a time window of 250-500 $\mathrm{ms}$, in relation to a pre-stimulus baseline. The baseline was defined as the mean voltage over $120 \mathrm{~ms}$ before the onset of the stimulus. Each subject was submitted to one block of 100 trials. In other words, the square was presented 100 times in each block. The stimulus appeared on the screen for 0.75 seconds, with the same time interval between stimuli.

Reaction time - Reaction time was used as an index of individuals' motor performance. Volunteers were responded to the target stimulus by pressing a button in a joystick The joystick was used to measure individuals' reaction time at each trial. Reaction times were subsequently averaged to yield a final value for each subject. M issed stimuli were not considered. Although reaction time is independent from ERP measures, it was used to verify subjects' alertness during the task.

Statistical analysis - Data were expressed as mean $\pm \mathrm{sd}$. A statistical analysis software (SPSS for Windows) was used. Specifically, a one-way Anova ( $p \leq 0.05$ ) was performed to compare the three conditions: treatment (C) and two placebos (P1 and P2). A T-test was subsequently used to compare $\mathrm{P} 1$ and $\mathrm{C}$.

\section{RESULTS}

Reaction time - The statistical analyses indicated a nonsignificant shortening in reaction time, as shown in Table 1.

EEG (visual evoked potential - P300) - Caffeine significantly shortened P300 latency at $F z(p<0.05)$. A similar trend was observed at $\mathrm{Cz}$, although statistical significance was not reached. Moreover, a non-significant increase at $\mathrm{Pz}$ was observed (Table 1). P300 latency at Fz, Cz and Pz are given in Figure 1. Specifically at Fz, P300 latency is shorter and amplitude is higher in the caffeine condition when compared to placebo control. ERP images are shown by Independent Component Analyses (ICA) (Fig 2).

Stroop test - Stroop execution time (SET) and Stroop Raw Score (SRS) values were compared among placebo 1, placebo 2, and caffeine conditions. SET reduced on P2 and C. SRS increased on $\mathrm{P} 2$ and C. Nevertheless, the observed differences were not statistically significant (Table 1).

\section{DISCUSSION}

The present study investigated the effects of caffeine on neuropsychomotor performance through the Stroop test, reaction time and P300 latency. These findings suggest positive effects of caffeine ingestion on P300, particularly in the frontal lobe. P300 latency on Fz (frontal electrode) was significantly shorter when caffeine was administered, as compared to placebo. It is known that frontal lobe activity is related to attentional demands ${ }^{21,22}$. Caffeine is considered a modulator of such processes, acting primarily as an antagonist of adenosine receptors in the brain ${ }^{5,23,24}$. On special conditions, i.e., sleepdeprivation or fatigue, adenosine action increases and the stimulant effects of caffeine are potentialized. Polich ${ }^{25}$ reported that the influence of caffeine on neurophysiological responses is related to the individual's alertness. Depending on the experimental conditions, caffeine ingestion will produce different effects on P300 latency. Reeves et al. ${ }^{19}$ observed a shortening of P300 latency but no changes in P300 amplitude with 13 caffeine-user subjects, submitted to four days of caffeine-deprivation. Recently, investigators observed hypo-

Table 1. Descriptive statistic analyses (mean $\pm s d$ ) of cognitive and neuromotor performance variables on $P 1, P 2$ and caffeine conditions.

\begin{tabular}{lcccccc}
\hline & $\begin{array}{c}\text { Reaction } \\
\text { time } \\
\text { (ms) }\end{array}$ & $\begin{array}{c}\text { Stroop } \\
\text { execution } \\
\text { time (s) }\end{array}$ & $\begin{array}{c}\text { Stroop raw } \\
\text { score }\end{array}$ & $\begin{array}{c}\text { Fz latency } \\
\text { (ms) }\end{array}$ & $\begin{array}{c}\text { Cz latency } \\
\text { (ms) }\end{array}$ & $\begin{array}{c}\text { Pz latency } \\
\text { (ms) }\end{array}$ \\
\hline Placebo 1 & $402 \pm 55$ & $106 \pm 14$ & $109 \pm 7$ & $361 \pm 33$ & $362 \pm 33$ & $366 \pm 34$ \\
Placebo 2 & $389 \pm 43$ & $103 \pm 14$ & $111 \pm 3$ & $352 \pm 36$ & $358 \pm 44$ & $363 \pm 34$ \\
Caffeine & $381 \pm 39$ & $103 \pm 18$ & $111 \pm 1$ & $334 \pm 30^{*}$ & $343 \pm 32$ & $367 \pm 33$ \\
\hline
\end{tabular}

* Significant difference between P1 and $(p<0.05)$. 


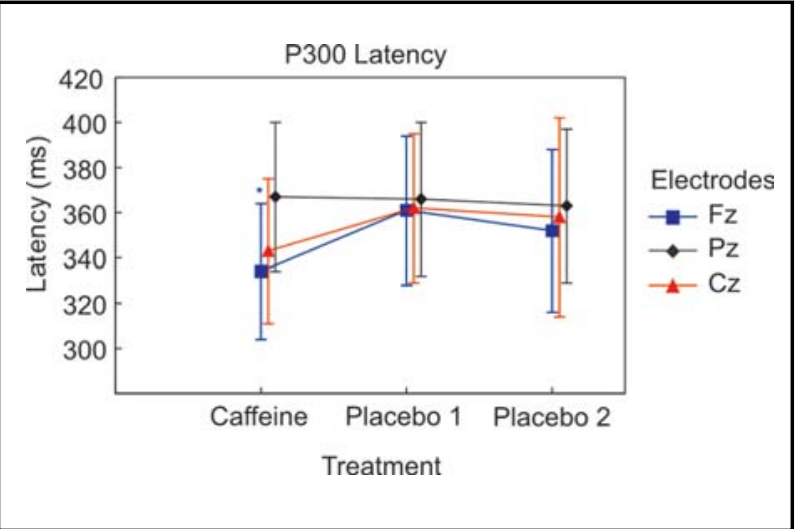

Fig 1. Latency means and s.d. for $F z, C z$ and $P z$ electrode sites in the $P 1, P 2$ and caffeine conditions. Significant difference between $C$ and $P 1\left({ }^{*} p<0.05\right)$. glycemia in normal ${ }^{26}$ and diabetic ${ }^{13}$ subjects through changes in P300 outcomes. In these studies, a decrease in amplitude and a delay in latency, in relation to low concentrations of plasmatic glucose, were observed. However, when caffeine was administered, there was a significant shortening of P300 latency. This response was associated with an increase of glucose usage by the brain and a decrease in cerebral artery blood flow velocity (from 64 to $49 \mathrm{~cm} / \mathrm{s}$ ) ${ }^{26}$. The degree of task difficulty seems to influence the effects of caffeine. Kawamura et al. ${ }^{18}$ observed that, depending on stimulus modality (oddball or single tone), P300 amplitude and reaction time would yield different results when $500 \mathrm{mg}$ of caffeine was administered.

Moreover, the present findings indicated an improvement

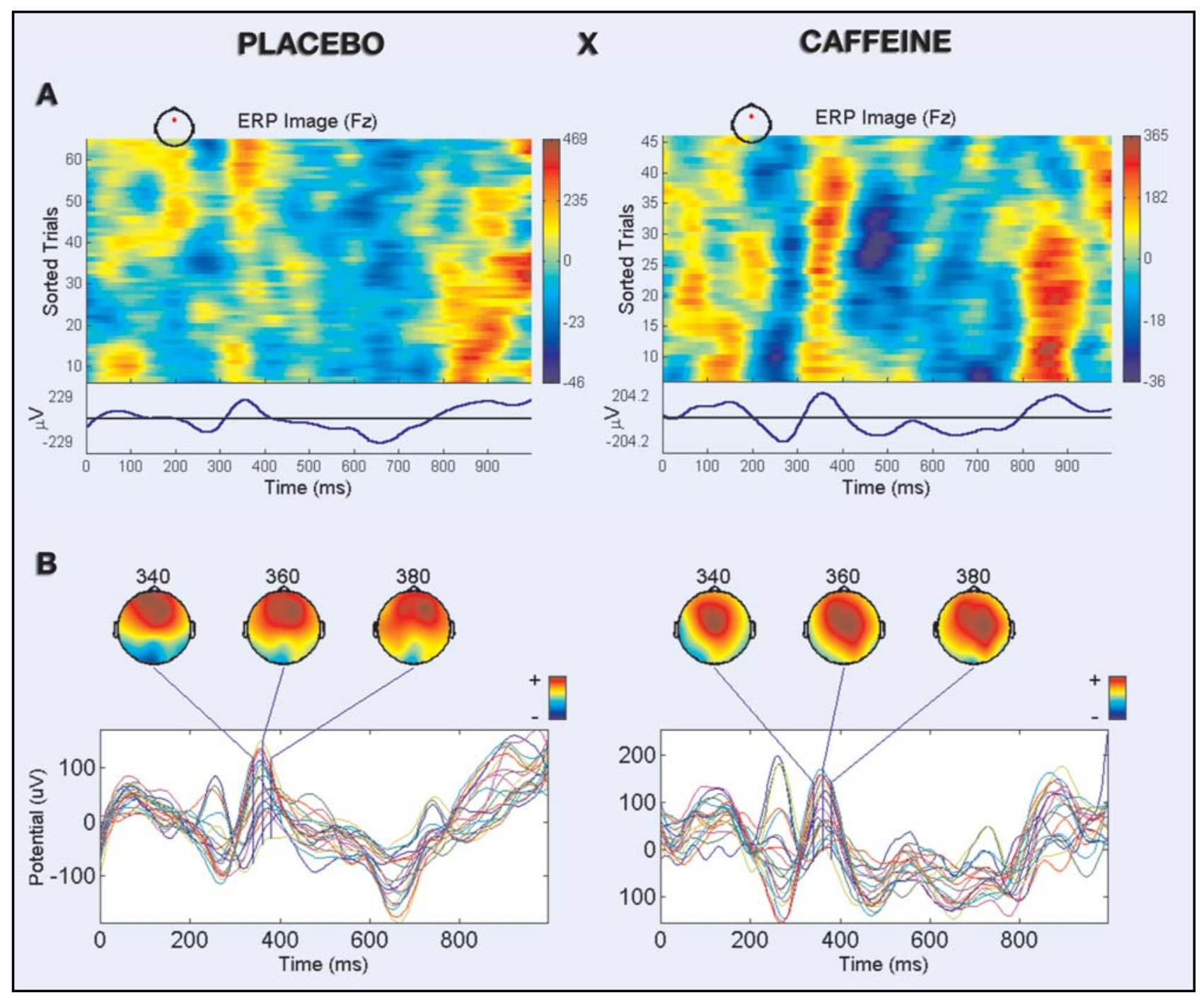

Fig 2. P300 plotted by Independent Component Analysis (ICA). A) ERP images of visual discrimination task (oddball), recorded at frontal electrode (Fz) of one subject on placebo (left) and caffeine (right) conditions, respectively. The average of all trials is shown for each ERP image (P300). (B) ERP waveforms and scalp current distributions on different latencies $(340,360$ and $380 \mathrm{~ms}$ ) for the same individual. 
trend on cognitive performance, through Stroop raw score and execution time, without any significant difference. Future studies, with a larger sample, are necessary to reach statistically significant results. Studies that employed this cognitive test along with caffeine ingestion presented conflicting results. Edwards et al. ${ }^{27}$ did not observe significant differences in Stroop performance when administering 125-250 mg of caffeine. Patat et al. ${ }^{17}$ contradicted these findings by showing a significant improvement in Stroop performance in individuals who took $600 \mathrm{mg}$ of caffeine. It must be stressed that, in our experiment, $400 \mathrm{mg}$ of caffeine was used. Our results in reaction time point out to a greater shortening between $\mathrm{P} 1$ and $\mathrm{C}$. However, these results were not statistically significant. Seidl et al. ${ }^{15}$ elaborated a nighttime experimental condition, and observed a lengthening of reaction time and P300 latency by the end of the test (midnight) in the placebo group, and maintenance of these variables in the caffeine group. Feinstein ${ }^{28}$, investigating the effects of practice on attention tests, observed a general improvement on the $\mathrm{P} 2$ that could be explained by practice. Nevertheless differences were not statistically significant.

In summary, the present study showed a positive effect of caffeine ingestion on cognitive performance, through P300 latency shortening in the frontal cortex. This result indicates an improvement of cortical activity. This mechanism is probably explained by its effects on central adenosine receptors. Adenosine is believed to be an inhibitory neuromodulator of the CNS with sedative-like properties. Caffeine appears to block the actions of endogenous adenosine at the adenosine $A_{1}$ receptor subtype by occupying those sites, and therefore, having a stimulant effect on certain types of behavior. How ever, future studies are needed to investigate the specific mechanisms responsible for these results. Experiments that aim to explain caffeine's contribution on cognitive and motor performance improvement on specials conditions must always be made in comparison to control groups. Caffeine usage may affect cerebral functioning more profoundly than has been previously suspected ${ }^{29}$. Other studies are necessary to try to investigate the influence of this psychoactive substance in CNS function. Studies with shorter latency potentials (P100, N100, P200 e N200) and qEEG will contribute to an enhanced understanding of the neurophysiological processes involving caffeine ingestion.

\section{REFERENCES}

1. Shapkin S. Effect of caffeine on cognitive function and psychophysiological status in man. Fiziol Chelovek 2002;28:144-150.

2. Perod A, Roberts A, McKinney W. Caffeine can affect velocity in the middle cerebral artery during hyperventilation, hypoventilation, and thinking: a transcranial Doppler study. J Neuroimaging 2000;10:33-38.

3. Sawynok J, Yaksh L. Caffeine as an analgesic adjuvant: a review of pharmacology and mechanisms of action. Pharmacol Rev 1993;45:43-85.

4. Lieberman H, Tharion W, Shukitt-Hale B, Speckman K, Tulley R. Effects of caffeine, sleep loss, and stress on cognitive performance and mood during U. S. Navy Seal training. Psychopharmacology (Berl) 2002;164:250-261.

5. Lieberman $\mathrm{H}$. The effects of ginseng, ephedrine and caffeine on cogni- tive performance, mood and energy. Nutr Rev 2001;59:91-102.

6. Magill RA, Waters WF, Bray GA, et al. Effects of tyrosine, phentermine, caffeine D-amphetamine, and placebo on cognitive and motor performance deficits during sleep deprivation. Nutr Neurosci 2003;6:237-246.

7. Johnson-Kohnson M, Kritz-Silverstein D, Barrett-Connor E, Morton D. Coffe comsumption and cognitive function among older adults. Amer J Epidemiol, 2002;156:842-850.

8. Polich J, Kok A. Cognitive and biological determinants of P300: an integrative review. Biol Psychol 1995;41:103-146.

9. Polich J. Neuropsychology of P3a and P3b: a theoretical overview. In. Arikan K, Moore N (eds.). Advances in electrophysiology in clinical practice and research. Kjellberg: Wheaton IL, 2002; in press.

10. Kugler C, Petter J, Taghavy A, et al. Dynamics of cognitive brain dysfunction in patients with cirrhotic liver disease: an event- releated $\mathrm{P} 300$ potential perspective. Eletroencephalogr Clin Neurophisiol 1994;91:33-41.

11. Yagi Y, Coburn K, Ester K, Arruda J. Effects of aerobic exercise and gender on visual and auditory P300, reaction time and accurancy. Eur J Appl Phisiol Occup Phisiol 1999;80:402-408

12. Bennigngton J, Polich J. Comparison of $\mathrm{P} 300$ from passive and active tasks for auditory and visual stimuli. Int J Psychophysiol 1999;34:171-177.

13. Debrah K, Sherwin R, Murphy J, Kerr D. Effects of caffeine on recognition of and physiological responses to hipoglycaemia in insulindependent diabetes. Lancet, 1996;347:19-24.

14. Jones E, Giger-Mateeva V, Reits D, Rielmslag F, Liberov B, Spekrijse H. Visual event-related potentials in cirrhotic patients without overt encephalopathy: the effects of flumazenil. Metab Brain Dis 2001;16:43-53.

15. Seild R, Peryl A, Nicham R, Hauser E. A taurine and caffeine-containing drink stimulates cognitive performance and well-being. Amino Acids 2000;19:635-642.

16. Polich J, Herbst K. P300 as a clinical assay: rationale, evaluation, and findings. Internat Psychophysiol 2000;38:3-19.

17. Patat A, Rosenzweiig P, Enslen M, et al. Effects of a new slow release formulation of caffeine on EEG, psycomotor and cognityive functions in sleep-deprived subjects. Hum Psychopharmacol 2000;15:153-170.

18. Kawamura N, Maeda H, Nakamura J, Morita K, Nakazaa Y. Effects of caffeine on event-related potentials: comparison of oddball with single-tone paradigms. Psychiatr Clin Neurosci 1996;50:217-221.

19. Reeves R, Struve F, Patrick G. The effects of caffeine withdrawal on cognitive P300 auditory and visual evoked potentials. Clin Eletroencephalogr 1999;30:24-27.

20. Jensen A, Rohwer W. The Stroop Color-word test: a review. Acta Psychol (Amst) 1965;25:36-93.

21. Zalla T, Pradat-Diehl P, Sirigu A. Perception of action boundaries in patients with frontal lobe damage. Neuropsychologia 2003;41:1619-1627.

22. Astafiev S V, Shulman G L, Stanley CM, Snyder AZ, Van Essen DC, Corbetta M. Functional organization of human intraparietal and frontal cortex for attending, looking, and poiting. J Neurosci 2003;23:4689-4699.

23. James E J. Caffeine \& health, San Diego, Academic Press, 1991.

24. Chou CC, Vickroy TW. Antagonism of adenosine receptors by caffeine metabolites in equine forebrain tissues. Amer Veter Res,2003;64:216-224.

25. Polich J. P300 in clinical applications. In: Niedermeyer E, Lopes da Silva F (eds.) Electroencephalography: basic principles, clinical applications and related fields 4.Ed. Baltimore: Urban \& Schwarzenberg 1999;1073-1091.

26. Kerr D, Sherwin R, Pavalkis F, et al. Effect of caffeine on the recognition of and responses to hypoglycemia in humans Ann Intern Med 1993;119:799-804.

27. Edward S, Brice C, Craig C, Penri-Jones R. Effects of caffeine, practice, and mode of presentation on Stroop task performance. Pharmacol Bioch Behav 1996;54:309-315.

28. Feinsten C, Brown R, Ron M. Effects of practice of serial tests of attention in healthy subjects. J Clin Exp Neuropsychol 1994;16:436-447.

29. Siepmann M, Kirch W. Effects of caffeine on topographic quantitative EEG. Neuropsychobiology 2002;45:161-166. 